\title{
Gas Tamponade for Myopic Foveoschisis with Foveal Detachment
}

\author{
Selim Bolukbasi*, Burak Erden, Akincakir, Mustafa Elcioglu and Serhat Mangan \\ Okmeydani Training and Research Hospital, Eye Clinic, Istanbu ${ }^{l}$
}

Submission: August 08, 2017; Published: September 18, 2017

*Corresponding author: Selim Bolukbasi, Okmeydani Training and Research Hospital, Eye Clinic, Istanbul, Tel: +905327007939;

Email: selimbolukbasi@hotmail.com

\section{Introduction}

Myopic foveoschisis (MF), is a split in the retinal layers at the macular area in eyes with pathologic myopia and it has been reported $9 \%$ to $34 \%$ of highly myopic eyes with posterior staphyloma [1,2]. Myopic macular retinoschisis can progress to more serious complications such as full-thickness macular hole and foveal retinal detachment during the follow-up period [3]. On the other hand, Polito et al. [4] reported one patient whose foveal detachment and macular retinoschisis disappeared after a spontaneous posterior vitreous detachment (PVD) during the follow-up period.

\section{Materials and Methods}

Preoperative and postoperative Snellen best corrected visual acuity (BCVA) was documented. Postoperative visits were scheduled at first, third, sixth months and one year. Slit-lamp examination, in direct fund us bio microscopy, and intraocular pressure measurements with applanation tonometry were carried out upon each visit. Axial length of the eye was measured with A-ultrasonography. The optical coherence tomography (OCT) scan was performed preoperatively and then at every visit postoperatively.

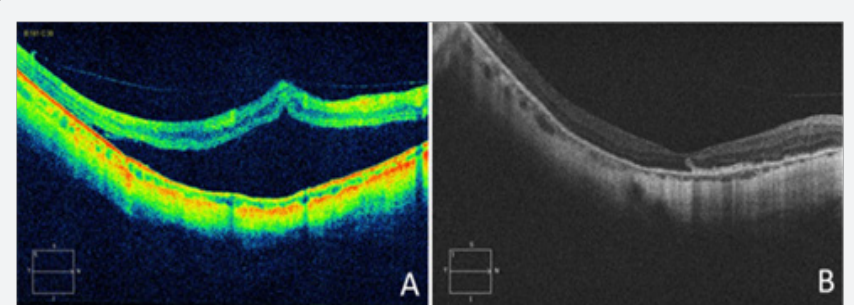

Figure 1: A: Foveoschisis with fovealdeteachment. B: The foveoschisis and foveal detachment seen in a resolved completely and posterior vitreus detached one month after the C3F8 injection. The BCVA improved from count fingers at two meters to 20/100 (Snellen).

A 68 year old man presented with the signs of myopicfoveoschisis in the right eye. The anterior segment was normal and the fund us revealed a myopic choroiditis with peripapillary atrophy, posterior staphyloma in both eyes. In addition there was macular atrophy in the left eye. BCVA was count fingers at 2 meters in the right eye and hand movement in the left eye. Axial length was $29.47 \mathrm{~mm}$ in the right eye, 29.38 in the left eye. OCT revealed an increased macular thickness, thinning and separation of the retina, foveal detachment in the right eye (Figure 1A). He received an intravitreal injection of $0.3 \mathrm{ml} \mathrm{C} 3 \mathrm{~F} 8$ and remained in the prone position for 7 days.

\section{Results}

One month after the injection BCVA improved from count fingers at 2 meters to 20/100 (Snellen), foveoschisis completely resolved and foveal deteachment disappeared in the right eye. At the end of the year, OCT still showed persistent attachment (Figure 1B). During the follow-up intraocular pressure was between $14-18 \mathrm{mmHg}$.

\section{Discussion}

MF is mainly characterized by an intraretinal cleavage in a myopic posteriors taphyloma, often combined with foveal detachment, lamellar macular hole, epiretinal membrane, orvitreomacular traction. Thus, Panozzo \& Mercanti [2] emphasized the high prevalence of epiretinal membranes in highly myopiceyes with foveoschisis. Isolated MF seems infrequent. The presence of foveald eteachment is a poor prognostic factor. There are lots of theoriesto explain the causes of the foveoschisis; vitreous traction of premacular vitreous cortex [5], rigidity of the internal limiting membrane (ILM) [6], stiffness of retinal vessels [7], progressive choroid atrophy [8] and posterior staphyloma [1] have all been proposed as reasons for the pathogenesis of foveoschisis. Ikuno et al. [9] were the first to suggest that gas injection promote posterior vitreous detachment for the theraphy of foveolar detachment.

There are several techniques to treat MF but the treatment of MF is still controversial. Options to treat MF include vitrectomy with or without ILM peeling $[10,11]$, macular buckling [12], a single injection of per fluoroethane [13] and a recently newly 
introduced suprachoroidal buckling technique [14]. Several authors have shown that foveoschisis resolved completely in more than $80 \%$ of their patients within one year after vitrectomy [15]. However, surgery on patients with high myopia may be hazardous. Complications after vitrectomy can be listed as follows; cataract, retinal detachment, full thickness macular hole, secondary glaucoma, and choroidal neo vascularization. On the other hand intra vitreal gas injection is a simple, minimally invasive procedure for the treatment of MF. It can be a wellaccepted alternative to vitrectomy for specific types of MF with comparable final anatomical results, with less tissue damage, morbidity, and expenses related to hospitalization. Repeated treatment is also possible in patients who exhibit an initial partial response or no response.

Because of the fact that the other eye of the patient had macular atrophy and the vision is poor, we planned a minimal surgical procedure for the eye that have MF. In our case, there was only mild vitreoretinal traction without epiretinal membranes. PVD caused by intraocular C3F8 injection and together with prone posturing promote retinal reattachmet. Gas tamponade pushes the retina back on and stretch the vitreous hyaloid, thus weakening the vitreomacular traction makes retina to stay attached easier. We think that if the pumping function of RPE cells over comes the force of vitreous traction the retina will stay attached. The use of intraocular expansible gas and prone posturing without vitrectomy, can be an alternative in selected cases of symptomatic macular foveoschisis, in the absence of epiretinal membranes. The status of the other eye may be important for choosing the best theraphy option.

Further studies are necessary in order to compare the indications, complications and visual outcome of the different surgical options: observation, gas injection, vitrectomy with or without ILM peeling and suprachoroidal buckling.

\section{Compliance with Ethical Standards}

\section{Ethical approval}

All procedures performed in studies involving human participants were in accordance with the ethical standards of the institutional and/or national research committee and with the 1964 Helsinki declaration and its later amendments or comparable ethical standards.

\section{Informed consent}

Informed consent was obtained from the patient included in the study.

\section{References}

1. Takano M, Kishi S (1999) Foveal retinoschisis and retinal detachment in severely myopic eyes with posterior staphyloma. Am J Ophthalmol 128(4): 472-476.

2. Panozzo G, Mercanti A (2004) Optical Optical coherence tomography findings in myopic traction maculopathy. Arch Ophthalmol 122(10): 1455-1460.

3. Benhamou N, Massin P, Haouchine B, Erginay A, Gaudric A (2002) Macular retinoschisis in highly myopic eyes. Am J Ophthalmol 133(6): 794-800.

4. Polito A, Lanzetta P, Del Borrello M, Bandello F (2003) Spontaneous resolution of a shallow detachment of the macula in a highlymyopiceye. Am J Ophthalmol 135(4): 546-547

5. Matsumura N, Ikuno Y, Tano Y (2004) Posterior vitreous detachment and macular hole formation in myopic foveoschisis. Am J Ophthalmol 138(6): 1071-1073.

6. Sayanagi K, Ikuno Y, Tano Y (2006) Tractional internal limiting membrane detachment in highly myopic eyes. Am J Ophthalmol 142(5): 850-852.

7. Ikuno Y, Gomi F, Tano Y (2005) Poten tretinal arteriolartraction as a possible cause of myopic foveoschisis. Am J Ophthalmol 139(3): 462467.

8. Fujiwara T, Imamura Y, Margolis R, Slakter JS, Spaide RF (2009) Enhanced depth imaging optical coherence tomography of the choroid in highly myopic eyes. Am J Ophthalmol 148(3): 445-450.

9. Ikuno Y, Sayanagi K, Ohji M, et al. (2004) Vitrectomy and internal limiting membranepeelingformyopicfoveoschisis. Am J Ophthalmol 137(4): 719-24.

10. Gaucher D, Haouchine B, Tadayoni R, Massin P, Erginay A, Benhamou N, Gaudric A (2017) Long-term follow-up of high myopic foveoschisis: natural course and surgicall outcome. Am J Ophthalmol 143(3): 455462 .

11. Shin JY, Yu HG (2012) Visual prognosis and spectral-domain opticalcoherenceto mography findings of myopicfoveoschisis surgery using 25-gauge transconjunctivalsuturelessvitrectomy. Retina 32(3): 486-492.

12.Zhu Z, Ji X, Zhang J, Ke G (2009) Posterior scleral reinforcement in the treatment of macular retinoschisis in highly myopic patients. Clin Experiment Ophthalmol 37(7): 660-663.

13. Gili P, Yanguela J, Martin JC (2010) Intraocular gas treatment for myopic foveoschisis. Eur J Ophthalmol 20(2):473-475.

14. EI Rayes EN (2014) Supra choroidal buckling in managing myopic vitreoretinal interface disorders: 1-year data. Retina 34(1):129-135.

15.Zhang T, Zhu Y, Jiang CH, Xu GZ (2017) Long-term follow-up of vitrectomy in patients with pathologic myopic foveoschisis. Int J Ophthalmol. 10(2): 277-284. 
This work is licensed under Creative Commons Attribution 4.0 License DOI:-10.19080/JOJO.2017.04.55568
Your next submission with Juniper Publishers will reach you the below assets

- Quality Editorial service

- Swift Peer Review

- Reprints availability

- E-prints Service

- Manuscript Podcast for convenient understanding

- Global attainment for your research

- Manuscript accessibility in different formats

( Pdf, E-pub, Full Text, Audio)

- Unceasing customer service

Track the below URL for one-step submission https://juniperpublishers.com/online-submission.php 